\title{
THE NECESSITY OF CAPACITY BUILDING FOR INDONESIA'S EFFECTIVE UTILIZATION OF WTO DISPUTE SETTLEMENT MECHANISM: IMPLEMENTATION OF GATT ARTICLE XX FOR TRADE AND ENVIRONMENT ISSUES
}

\author{
Windu Kisworo ${ }^{1}$
}

\begin{abstract}
Abstrak
The World Trade Organization Agreement, aimed to also protect the environment, provides a special provision on environment under article $X X$. Any dispute arose between parties in respect to the article should be settled trough the WTO Dispute Settlement Mechanism. Although environmental protection should be sought in trade, it is often problematic for developing countries. They generally lack an adequate domestic environmental legislation and its enforcement because they place greater priority on economic development. Indeed, there have been a number of cases fought between developing countries and developed countries on this very issue within the WTO Dispute Settlement Mechanism. In addition, there are several conditions that might prevent them of using the mechanism effectively which includes: lack of understanding of WTO law and its jurisprudences, lack of institutional capacity, and the fear of retaliation from developed countries when bringing the claim against developed countries to Dispute Settlement Mechanism. Indonesia, as one of developing countries also faces the above three problems. This paper will discuss what Indonesia need to prepare so that they can use the Dispute Settlement Mechanism effectively to resolve any dispute (if any) with other country, particularly in respect to the violation of the article XX under the WTO Agreement.
\end{abstract}

\section{Introduction}

Despite the fact that developing countries are an important group of countries in the World Trade Organization (WTO) system, they benefit less from the WTO system than developed countries do. Developing countries outnumber developed countries in the total membership: about two thirds of around 150 WTO members are from developing countries. ${ }^{2}$ In order to

${ }^{1}$ Associate Researcher The Indonesian Center for Environmental Law (ICEL) and Program Officer The Asia Foundation, Indonesia. Correspondence: wkisworo@gmail.com. 
decrease the inequality of benefits for developing and developed countries, the WTO provides some special and differential treatment to developing countries. Nevertheless, developing countries still face difficulties in fully benefitting from WTO system. One of those difficulties is, inter alia, in the use of trade-related measures for the protection of the environment and human health.

The relationship between trade and environment has been one of the major topics on the international scene. ${ }^{3}$ While some argue that environmental protection measures could create obstacles for trade policies, most scholars and practitioners argue that the increasing trade between countries has caused greater problems for the environment. ${ }^{4}$ This concern results from the fact that global environmental integrity has deteriorated rapidly in large part due to unregulated (or poorly regulated) economic activities. As a major trade regime, the WTO has focused primarily on the negative impact of environmental protection on trade since its establishment in 1995. It was only after the case of United States - Restriction on Import of Tuna (Tuna-Dolphin $I)^{5}$ that WTO started paying attention to the negative impacts of the trade regime on the environment and environmental policies. ${ }^{6}$

Although environmental protection should be sought in trade, it is often problematic for developing countries. Indonesia's example is illustrative. For one thing, Indonesia generally does not possess the technologies for widespread production of environmentally friendly products. Also, Indonesia lacks an adequate domestic environmental legislation and enforcement mechanisms because the government places greater priority on economic development. Further, Indonesia's lack of environmental concern gives importers of Indonesian-made products grounds

2 World Trade Organization, 'Understanding the WTO: Developing Countries', at $<\mathrm{http}: / /$ www.wto.org/english/thewto_e/whatis_e/tif_e/dev1_e.htm>, at 16 January 2006.

3 Anupal Goyal, The WTO and International Environmental Law: Toward Reconciliation (2006), 1.

${ }^{4}$ Ibid.

5 United States - Restriction on Import of Tuna, Panel report Doc. DS 21/R, circulated at 3 September 1991 (unadopted), (US - Tuna/Dolphin I), $<$ http://www.worldtradelaw.net/ reports/gattpanels/tunadolphinI.pdf>, at 10 January 2007.

6 Nathalie Bernasconi-Osterwalder, WTO's Contribution To Sustainable Development Governance: Balancing Opportunities And Threats, (paper presented at WTO's Contribution to Sustainable Development Governance: Balancing the Opportunities and Threats Conference, Paris, 20 \& 21 October 2005), 1. 
to accuse Indonesia of environmental deterioration, which could itself result in trade disputes. Indeed, there have been a number of cases fought between developing countries and developed countries on this very issue within the WTO Dispute Settlement Mechanism. The same thing could happen to Indonesia an day.

While it is important for Indonesia to develop domestic environmental legislation, its lack of environmentally friendly technologies makes it impossible for the country to deal with this issue to the same extent as developed countries do. Taking into account this technological divide between Indonesia and the developed countries, it is fair for Indonesia to defend its position in environment-related trade disputes. However, like other developing countries, Indonesia has three main obstacles to effective utilization of the Dispute Settlement Mechanism: inadequate understanding of WTO law and its jurisprudence, the lack of institutional capacity for dispute settlement, and the fear of retaliation from developed countries.

Among these three obstacles for the protection of the country under the Dispute Settlement Mechanism, this paper focuses on the lack of WTO law and its jurisprudences, especially regarding the interpretation of the chapeau of article XX, article XX(b) and XX(g) of the General Agreement on Tariffs and Trade (GATT) ${ }^{7}$. While the lack of institutional capacity and the fear of retaliation are serious as well, the lack of understanding of the Dispute Settlement Mechanism's operation makes fair dispute resolution impossible for Indonesia, regardless of whether its adversary is a developed nation or not. This paper argues that what is critical for Indonesia to develop an adequate understanding of the WTO Dispute Settlement Mechanism by engaging in capacity building. Among the broad options for capacity building, Indonesia should enhance its human resources in the area of the chapeau of Articles XX, XX(b) and XX (g) of the GATT, where it will have the best chance to win meaningful environmental protections.

The first part of this essay will analyze developing countries' utilization of the Dispute Settlement Mechanism under WTO system. The aim of this section is to examine the problems developing countries face in using the Dispute Settlement Mechanism effectively. The second part of the essay will discuss the relationship between trade and environment, particularly by analyzing Article XX of the GATT in regard to trade and environment. It will also examine some important cases that were decided by the WTO panels and Appellate Body. The third and the final part of the essay

${ }^{7}$ Marrakesh Agreement Establishing the World Trade Organization, opened for signature 15 April 1994, 1867 UNTS (entered into force 1 January 1995), Annex 1A (General Agreement on Tariffs and Trade) 1867 UNTS 190 ('GATT'). 
will draw together a number of conclusions on various legal issues that face Indonesia's trade and environment question.

\section{Dispute Settlement Mechanism and Developing Countries}

The WTO was established by "Marrakesh Agreement Establishing the World Trade Organization", so called "Marrakesh Agreement", opening for signature on 15 April 1994, and entering into force on 1 January $1995 .{ }^{8}$ Developing countries are significant players in the WTO system, especially due to the large proportion of developing countries in the WTO's total membership.

The WTO provides differentiated treatment for developing countries. This includes the special provision on developing countries in WTO law, the development of special bodies for developing countries such as the Commission on Trade and Development, and technical assistance provided by the WTO secretariat. However, despite this special treatment, the WTO gives less benefit to developing countries than to developed countries, which causes criticism that this international trade regime is an agenda only of developed countries. Developing countries have less economic leverage than developed countries, often have higher unemployment rates, and generally lack production technology. These characteristics often cause disadvantages for developing countries in trade agreements that are exclusively negotiated by developed countries. In most of the negotiations and agreements on trade liberalization, developed countries can use their economic strength to leverage for lopsided benefits, particularly in sectors that are important to developing countries, such as agriculture. Developing countries have long called for an international trade agreement that better addresses their needs, including the request for a more effective Dispute Settlement Mechanism.

It is necessary to understand the fundamentals of the WTO Dispute Settlement Mechanism in order to examine its use in trade and environment disputes by developing countries. The WTO Dispute Settlement Mechanism was created based on the Article XXII and XXIII of the GATT, which preceded the WTO rules. As a result of the Uruguay Round, the Dispute Settlement Understanding (DSU) was created, which established the WTO

${ }^{8}$ Marrakesh Agreement Establishing the World Trade Organization, opened for signature 15 April 1994, 1867 UNTS (entered into force 1 January 1995). ('Marrakesh Agreement'). 
Dispute Settlement Mechanism. ${ }^{9}$ Based on this mechanism, WTO member countries are to negotiate for the settlement of disputes arising from the implementation of the WTO Agreement. In this procedure, the Dispute Settlement Body (DSB) has the authority to establish panels, adopt panel reports, observe closely the implementation of recommendations, and approve measures for parties who suspend the implementation of the covered agreement. $^{10}$ There has been a wide range of cases arising under WTO agreements, such as on trade in goods, services, and intellectual property. This is a major difference from the dispute resolution system under the GATT. The disputes that were brought by applicants to the GATT were mostly about the interpretation of the GATT provisions. ${ }^{11}$

There are several stages in a dispute settlement under the DSU. The first stage requires the parties to undertake bilateral consultation. ${ }^{12}$ The objective of this stage is to enable parties in the dispute to have clear information on the legal claim and factual situation of the dispute. In disputes between a developing and developed countries, special attention is paid to developing countries by including 'at least one panelist from developing country member'. ${ }^{13}$ After this process, the panel must take the following steps within 60 days: examine the facts and arguments; hold a meeting between the parties and interested third parties; conduct an interim review; draft a conclusion and recommendation; and provide a report to the parties and the DSB. ${ }^{14}$

Additionally, a standing appellate body may be established by the DSB to hear appeals from the panel cases. Appeals, however are limited to issues of law covered in the panel report and to legal interpretations produced by the panel.

Finally, the DSB adopts the report circulated by the Appellate Body to implement the recommendation. The respondent is given 30 days after the day of adoption by the DSB of the panel or Appellate Body report to inform

9 Marrakesh Agreement, above n 9, Annex 2, (Understanding of Rules and Procedures Governing the Settlement of Disputes), (Dispute Settlement Understanding).

${ }^{10} \mathrm{Ibid}$, article 2 .

${ }^{11}$ Bernard M. Hoekman and Michel M. Kostecki, The Political Economy of the World Trading System: The WTO and Beyond, $2^{\text {nd }}$ ed, 2001, 74.

${ }^{12}$ See Dispute Settlement Understanding, above n 11, article 4.

${ }^{13}$ See Dispute Settlement Understanding, above n 11, article 8.

${ }^{14}$ Hoekman, above n 13, 77. 
its intentions to DSU with respect to implementation of the recommendations. When immediate compliance is infeasible, the member concerned shall be given a 'reasonable period of time' to do so. ${ }^{15}$ If there is disagreement between the parties to the dispute as to the adequacy of the implementing measures, the complaining party can request a panel, including to the original panel, to affirm on this matter. ${ }^{16}$ Malaysia utilized this request in the case of United States - Import Prohibition of Shrimp and Shrimp Products $^{17}$.

Furthermore, if the member concerned fails to implement the recommendation within this 'reasonable period of time', parties may negotiate compensation and suspension of the full implementation of such a recommendation. ${ }^{18}$ However, it must be conducted in conformity with the covered agreement. The failure to agree with the compensation or suspension gives the right to any party initiating the dispute to ask the DSB 'to suspend the application to the Member concerned of concessions or other obligations under the covered agreements'. 19

The WTO Dispute Settlement Mechanism is a significant function to gain benefits from international trade for developing countries, the majority of the WTO members. Under the Dispute Settlement Mechanism's ensurance for WTO members to be protected from protectionist practices of their trading counterparts, developing countries can maintain great incentives for market liberalization in sectors where they have critical interests in export. ${ }^{20}$

The Dispute Settlement Mechanism has greater significance for developing countries under WTO than under GATT. According to Busch and Reinhart, while the proportion of developing countries involved as respondents was only $8.0 \%$ among the total number of respondents under the GATT (1948 - 1994) system, it has increased to $37.0 \%$ under the WTO

${ }^{15}$ See Dispute Settlement Understanding, above n 11, article 21(3).

${ }^{16}$ See, Dispute Settlement Understanding, above n 11, article 21(5).

${ }^{17}$ United States - Import Prohibition of Shrimp and Shrimp Products, Appellate Body Report (WT/DS58/R/AB/RW) 22 October 2001, par 119. <http://www.law.georgetown. edu/iiel/cases/US-Shrimp(ab)(21.5).pdf>, at 27 January 2007.

${ }^{18}$ See Dispute Settlement Understanding, above n 11, article 22(2).

${ }^{19}$ See Dispute Settlement Understanding, above n 11, article 22(2).

20 Chad P. Brown, Developing Countries as Plaintiffs and Defendants in the GATT/WTO Trade Disputes, 1, <http://people.brandeis.edu/ cbown/papers/developing.pdf>, at 5 January 2007. 
$(1995-2000))^{21}$ On the other hand, however, the proportion of developing countries that filed complaints has decreased slightly from $30.6 \%$ under the GATT to $29.2 \%$ under the WTO $(1995-2000){ }^{22}$ These figures indicate that while the involvement of developing countries in the Dispute Settlement Mechanism under the WTO is greater compared to that under the GATT, developing countries are defendants in more cases than not in those disputes under the WTO system. This shows increased necessity for developing countries to utilize the Dispute Settlement Mechanism for better protection of themselves.

However, there are three major factors that prevent them from using this mechanism effectively, most of which are due to the fact that they are not equipped with adequate resources to participate in the process. Firstly, developing countries lack the legal expertise for understanding the complex web of the WTO law. Lawyers from developing countries have to make a great effort to read and understand the WTO law, that covers a wide range of aspects, for the protection of the countries. Kenneth Abboth et al analyze that the WTO law, compared to the GATT rules, involves greater legalization, such as binding obligations and precise rules. Moreover, it sends delegations to a dispute settlement institution. ${ }^{23}$ Not only is the understanding of these highly legalized rules challenging for lawyers in developing countries, there is even greater challenge for them: they have to understand how the WTO panels and Appellate Body develop their legal arguments before deciding to be plaintiffs or to prepare themselves as defendants on a particular dispute. In addition, although the WTO law does not formally adopt a common law approach, panels and the Appellate Body guide their legal reasoning of the decision with the WTO legal jurisprudence. This has caused lawyers from developing countries, which adopt a civil law approach, even greater difficulty in understanding the WTO law and its cases that are mostly decided by using a common law approach. ${ }^{24}$

${ }^{21}$ Marc L. Busch and Eric Reinhardt (2000), "Testing International Trade Law: Empirical Studies of GATT/WTO Dispute Settlement", as quoted by Bernard M. Hoekman and Michel M. Kostecki, "The Political Economy of the World Trading System: The WTO and Beyond", $2^{\text {nd }}$ ed, 2001, p. 395.

${ }^{22}$ Ibid.

${ }^{23}$ Kenneth Abbott, et. al., 'The Concept of Legalization', 54, International Organization, 401 as quoted by Gregory Shaffer, "How to Make the WTO Dispute Settlement System Work for Developing Countries: Some Proactive Developing Countries Strategies", 2003, ICTSD Resource Paper, 5, 2003. 
The second factor that prevents developing countries from using the system effectively is their lack of institutional capacity, particularly financial capacity. ${ }^{25}$ Litigation at international level is highly specialized and expensive. For example, in Japan - Measures Affecting Consumer Photographic Film and Paper ${ }^{26}$, the cost for hiring the lawyer was about US\$10 million. ${ }^{27}$ Many developing countries would not be able to afford such expensive cost because, in average, the cost of hiring international private lawyer that they might afford ranges from $\$ 200$ to $\$ 600$ (or more) an hour. $^{28}$

The complexity of WTO rules and the WTO institutional structure has rendered developing countries incapable to follow all the WTO developments. There are over 70 different WTO councils, committees, working parties, and other groupings involving more than 2,800 meetings every year. ${ }^{29}$ It is almost unfeasible for developing countries to be involved effectively in all those institutional structures due to the lack of national support, particularly in allocating financial support to send delegations for effective negotiation of international trade. Furthermore, developing countries tend to assign a delegation from relatively low positions within governmental hierarchies on trade matters, which could negatively impact

24 'By adding 26,000 pages of new treaty text, not to mention a rapidly burgeoning case law; by imposing several new stages of legal activities per dispute, such as appeals, compliance reviews, and compensation arbitration; by judicial proceedings, and thus putting a premium on sophisticated legal argumentation as opposed to informal negotiation; and by adding a potential two years or more to defendants' legally permissible delays in complying with adverse rulings, the WTO reforms have raised the hurdles facing [developing countries] contemplating litigation.'.

${ }^{25}$ Gregory Shaffer, "The challenge of WTO Law: Strategies for Developing Country Adaptation”, (World Trade Review, 2006), 5:2, 177, 177.

${ }^{26}$ Japan - Measures Affecting Consumer Photographic Film and Paper, Panel Report (WT/DS44/R), 31 March 1998, <http://www.worldtradelaw.net/reports/wtopanelsfull/ japan-film(panel)(full).pdf $>$, accesed at 5 January 2007.

${ }^{27}$ Gregory Shaffer, "How to Make the WTO Dispute Settlement System Work for Developing Countries: Some Proactive Developing Countries", (ICTSD Resource Paper, 2003), 5, p. 16.

\section{${ }^{28}$ Ibid.}

${ }^{29}$ Gary Sampson, "Trade, Environment and the WTO: The Post-Seattle Agenda", (2000), Overseas Development Council, 24 as quoted by Gregory Shaffer, "The challenge of WTO Law: Strategies for Developing Country Adaptation”, (World Trade Review, 2006), 5:2, $177,181$. 
the negotiation processes. ${ }^{30}$ This is in a clear contrast to the United States and the European Union that assign people from a cabinet level position to international trade matters. ${ }^{31}$

The third factor that prevents developing countries from using the WTO Dispute Settlement Mechanism effectively, particularly in bringing their claims, is their fear of political and economic pressure from member countries that have much bigger leverage economically and politically, such as the United States and European Union. ${ }^{32}$ Developing countries might consider not initiating a dispute against developed countries because they fear that it may result in an undesirable result, such as the suspension of foreign aid. Even if a developing country gains a legal victory, they might face retaliation from a developed country of a bigger market size. Due to these concerns, developing countries may consider not to file complaint against developed countries in the first place. ${ }^{33}$ Indeed, many scholars argue that pressures from developed countries are major reasons to create unfair international trade that could hinder development of developing countries. Joseph Stiglitz and Andrew Charlton argue that, in order to promote development, international trade should rely on 'economic analyses' and 'social justice' rather than 'economic power' and 'special interest'. ${ }^{34}$

Although many developed countries lately discuss the reform of WTO Dispute Settlement Mechanism, developing countries do not, or cannot, focus their attention on such reform issue due to these three factors. Developing countries have got their hands full with defending themselves when developed countries file disputes against them, and increasing their legal expertise so as to be able to reduce the gap with developed countries. ${ }^{35}$ Given that the DSU provides special treatment for developing countries to

30 Shaffer, "The challenge of WTO Law: Strategies for Developing Country Adaptation", above n 30, 179-180.

${ }^{31}$ Ibid.

${ }^{32}$ March L. Busch, "The WTO Dispute Settlement Mechanism and Developing Countries", Trade Brief on WTO and Dispute Settlement, (2004).

${ }^{33}$ Ibid.

${ }^{34}$ Joseph E. Stiglitz and Andrew Charlton, "Fair Trade For All: How Trade Can Promote Development", (2006), p. 5.

35 Valentina Delich, "Developing Countries and the WTO Dispute Settlement System", in Bernard Hoekman (ed) et al, "Development, Trade, and the WTO: A Hand Book", (2002), p. 71, 79. 
have prompt compliance with recommendations or rulings of the DSB, '[p]articular attention should be paid to matters affecting the interests of developing country Members with respect to measures which have been subject to dispute settlement ${ }^{36}$ It should cover a wide range of efforts which aim to eliminate the above mentioned three factors that prevent developing countries from using the dispute settlement system effectively.

\section{Important Legal Issues under Article XX of the GATT}

It is important to understand the relationship between trade and environment, which is one of the major issues at the international level, before discussing specifically the interpretation of article XX of the GATT. The globalization of economy has integrated the national economies of states. Under such global economic structure, production of goods and services are sourced from around the globe in a system held together by powerful communication and information technologies. ${ }^{37}$ However, the economic globalization also increases inequality between developed and developing countries. Although average global income exceeds US $\$ 5,100$ per person a year, which is about US\$14 a day, 2.8 billion people still strive with income of less than US\$2 a day. ${ }^{38}$

In addition, the deepening globalization also causes another global issue, namely, enormous environmental change. It includes depletion of the ozone layer, global warming, endangered species extinction, and the loss of biodiversity. The research conducted by the Millennium Ecosystem Assessment shows how the trends of the ecosystem and human well-being have changed over the years both positively and negatively: ${ }^{39}$

${ }^{36}$ Dispute Settlement Understanding, above n 11, article 21(2).

37 International Institute for Sustainable Development and United Nation Environmental Program, $2^{\text {nd }}$ ed, (Environment and trade: A Handbook, 2005), p., 1.

${ }^{38}$ Ibid.

${ }^{39}$ The Millennium Ecosystem Assessment, at, <http://www.millenniumassessment. org//en/Products.Global.Condition.aspx>, accesed at 18 January 2007.

The Millennium Ecosystem Assessment (MA) is an international work program designed to meet the needs of decision makers and the public for scientific information concerning the consequences of ecosystem change for human well-being and options for responding to those changes. The MA was launched by U.N. Secretary- General Kofi Annan in June 2001 and was completed in March 2005. It will help to meet assessment needs of the Convention on Biological Diversity, Convention to Combat Desertification, the Ramsar 


\begin{abstract}
Humans have changed ecosystems more rapidly and extensively in the last 50 years than in any comparable period of human history. We have done this to meet the growing demands for food, fresh water, timber, fiber, and fuel. While changes to ecosystems have enhanced the well-being of billions of people, they have also caused a substantial and largely irreversible loss in diversity of life on Earth, and have strained the capacity of ecosystems to continue providing critical services. ${ }^{40}$
\end{abstract}

Economic globalization, the improvement of living conditions, and the environmental change are interrelated. Although trade can create wealth to enhance human well-being, and although development can reduce the gap between the rich and the poor, the current implementation of trade and development does not reflect the full cost of environmental damage, which is seriously threatening the earth's ecosystem. ${ }^{41}$ Nevertheless, global economic activities, which is causing environmental change in a large scale, is further expanding. ${ }^{42}$ It is becoming increasingly important to build strategies to meet the objectives of all these intertwined issues without seriously damaging any one of them. This strategy should especially pay attention on the relations between trade and environment.

The cornerstone for the harmonious relationship between trade and environment is in the link between international trade policies and Multilateral Environmental Agreements (MEAs). The current liberal trade regime is founded based on the legal principle of the GATT in 1994 and its predecessor in 1947. The main objective of the GATT was to promote economic development and to manage economic globalization. The GATT was comprised of two basic directions: to develop requirements to lower and eliminate tariffs as well as to create obligations that prevent or eliminate non-

Convention on Wetlands, and the Convention on Migratory Species, as well as needs of other users in the private sector and civil society. If the MA proves to be useful to its stakeholders, it is anticipated that such integrated assessments will be repeated every 5- 10 years and that ecosystem assessments will be regularly conducted at national or sub-national scales.

${ }^{40}$ Millennium Ecosystem Assessment (2005) 'Global Assessment Report: Current State and Trends, at, <http://www.millenniumassessment.org//en/Products.Global. Condition.aspx $>$, accesed at 18 January 2007.

${ }^{41}$ International Institute for Sustainable Development and United Nation Environmental Program, above n 43, 4-5.

42 International Institute for Sustainable Development and United Nation Environmental Program, above n 43, 2. 
tariff barriers to trade that could be an impediment to trade. ${ }^{43}$ When GATT 1947 was drafted, the protection of the environment was not a major issue. Indeed, the GATT 1947 does not contain the word 'environment'.

On the other hand, the MEA is aimed to protect global environmental conditions which are affected by global economic activities. There are several MEAs that have a direct linkage with trade. For example, The Convention on International Trade in Endanger Species (CITES) regulates trade in relation with certain species and their parts. ${ }^{44}$ The Vienna Convention for the Protection of the Ozone Layer was also agreed in order to protect the ozone layer from the depletion caused by industrial chemical activities. ${ }^{45}$ The Basel Convention on the Control of Transboundary Movements of Hazardous Wastes and Their Disposal provides some conditions to minimize the production of hazardous waste, control and reduce its transboundary movement, protect human health and the environment, and regulate disposal of hazardous waste. ${ }^{46}$ On biodiversity issue, The Biological Convention on Biological Diversity and The Cartagena Protocol on Biosafety aim to conserve biological diversity, promote the sustainable use of its components, and promote fair and equitable sharing of the benefits arising from the use of genetic resources. ${ }^{47}$ The United Nations Framework Convention on Climate Change and the Kyoto Protocol to the United Nations Framework Convention on Climate Change were agreed to decrease the emission of various greenhouse gases that contribute to global climate change. ${ }^{48}$ The

43 International Institute for Sustainable Development and United Nation Environmental Program, above n 43, 25.

44 The Convention on International Trade in Endanger Species, 12 I.L.M. 1085(1973); 993 U.N.T.S. 243, Signed on March 3, 1973, entered into forced July 1, 1975.

45 Vienna Convention for the Protection of the Ozone Layer, UNEP Doc. IG.53/5; 26 I.L.M. 1529 (1987), signed on March 22, 1985, entered into forced September 22, 1988.

${ }^{46}$ Basel Convention on the Control of Transboundary Movements of Hazardous Wastes and Their Disposal, 28 I.L.M. 657 (1989), signed on March 22, 1989, entered into force May 5, 1992.

${ }^{47}$ Convention on Biological Diversity, 31 I.L.M. 818 (1992), signed on June 5, 1992, entered into force December 29, 1993; The Cartagena Protocol on Biosafety, signed on January 29, 2000, entered into force September 11, 2003.

48 United Nations Framework Convention on Climate Change, 31 I.L.M. 849 (1992), signed on May 29, 1992, entered into force March 21, 1994; Kyoto Protocol to the United Nations Framework Convention on Climate Change, FCCC/CP/1997/L.7/add.1, signed on December 11, 1997, entered into force February 16, 2005. 
strong need to adopt requirements set up in these conventions and protocol is evidenced by the current report of the summary of the policy makers of the Working Group I to the Fourth Assessment Report of the Intergovernmental Panel on Climate Change, $2007 .^{49}$ This report identified some major facts where emissions that are created from the industrial activities give effect to the current global warming.

The MEA adopts several principles in meeting its environmental goals. Besides being developed specifically in the convention, these principles also came from a wide variety of sources, which include the United Nations General Assembly Resolution, the decision of international arbitration, and the judicial decision of the International Court of Justice. David Hunter et al categorize the principles into three. The first is principles that 'simply reflect the application of general international law principle to environmental issues specifically ${ }^{50}$ Examples include the principle of good neighborliness and the duty to cooperate, which require states 'to achieve international cooperation in solving international problem of an economic, social, cultural, or humanitarian character'. ${ }^{51}$ After the 1972 Stockholm Conference, the UN Charter 'implicitly include cooperation regarding the global environment' as areas of duty to cooperate. ${ }^{52}$

The second category is principles on obligations not to cause environmental harm outside national jurisdiction. ${ }^{53}$ This has been widely considered as customary international environmental law. The examples are principles that provide rules on state sovereignty and state responsibility.

Finally, there are also some concepts that probably cannot be viewed as customary international law. ${ }^{54}$ The examples include precautionary principle and common but differentiated responsibilities which are essential for the relationships between trade and environment. The precautionary principle contains the obligation to anticipate and mitigate possible

${ }^{49}$ Summary of the policy makers of the Working Group I to the Fourth Assessment Report of the Intergovernmental Panel on Climate Change, 2007, <http://www.ipcc.ch/ SPM2feb07.pdf $>$, accesed at 25 January 2007.

${ }^{50}$ David Hunter, James Salzman, and Durwood Zaelke, International Environmental Law \& Policy, $2^{\text {nd }}$ ed, (2002), p. 319.

${ }^{51}$ The United Nation Charter, article 1.3.

${ }^{52}$ Hunter, et al, above n 71,375 .

${ }^{53}$ Hunter, et al, above n 71,319 .

${ }^{54}$ Hunter, above n 71, 319. 
environmental damages that occur especially due to the lack of scientific certainty. The common but differentiated responsibilities give various levels of commitments to the ratifying countries in implementation of the treaty. These commitments are relevant for special and differential treatment to developing countries within the WTO system.

The goals and implementation of international trade law sometimes conflicts with MEAs. Anupam Goyal identifies that the conflicts could occur in several areas. ${ }^{55}$ The first area concerns the potential tools of environmental protection, such as subsidies to assist cleaning up the environment. These tools could violate the Basis principle under GATT. The second area concerns any measures under international environmental law that target uncooperative countries which violate the Most Favored Nation (MFN) principle. The third area concerns inconsistencies between environmental regulations and other regulations. For example, even when one country attracts investment by specializing in trade of goods that are produced by harming the environment, the punishment of these environment-unfriendly products by levying special import taxes would violate the MFN principle. The fourth area that conflict between trade and environment could occur is in where trade-related laws could cause deterioration of the harmonization of health and safety standards. When a importing country have laws that set high level of environment protection in the production of goods, it could be considered to be a trade barrier for those countries that cannot meet the environmental requirement.

This categorization shows that international trade law, particularly the WTO law, and international environmental law comprise different perspectives that could create conflicts for their implementation. It is further causing a debate whether the use of trade-related measures for the protection of the environment and human health are permissible under the WTO framework. ${ }^{56}$ Despite these potential conflicts and a debate on this issue, as a member country of WTO and a party to some MEAs, it is necessary for Indonesia to attempt to meet the goals of both WTO laws and MEAs. Such attempt has been subject to ongoing economic globalization on the international level.

There are some agreements on trade which have environmental implication other than the GATT. They include General Agreement on Trade in Services (GATS), ${ }^{57}$ The Agreement on the Application of Sanitary and

${ }^{55}$ Goyal, above n 4, 5 .

${ }^{56}$ Nathalie Bernasconi-Osterwalder, et al., Environment and Trade, (2005), 76. 
Phytosanitary Measures (SPS), ${ }^{58}$ Technical Barrier to Trade (TBT) ${ }^{59}$, and Trade Related Aspects of Intellectual Property Rights (TRIPs) ${ }^{60}$. This essay, particularly aiming to analyze developing countries' understanding of WTO law on trade and environment, limits the discussion to the chapeau of article $\mathrm{XX}$, article XX(b), and article XX(g) of the GATT.

Although GATT does not explicitly mention the word 'environment', there are some articles that impliedly mention the need to protect the environment. Essentially, article XX of the GATT 'lays out a number of specific instances in which WTO Members may be exempted from GATT rules'. ${ }^{61}$ The chapeau of this article mentions that:

Subject to the requirement that such measures are not applied in a manner which would constitute a means of arbitrary or unjustifiable discrimination between countries where the same conditions prevail, or a disguised restriction on international trade, nothing in this Agreement shall be construed to prevent

${ }^{57}$ Marrakesh Agreement, above n 9, Annex 1B (General Agreement on Trade in Services) 1869 UNTS 183.

${ }^{58}$ Marrakesh Agreement, above n 9, Annex 1A (Agreement on the Application of Sanitary and Phytosanitary Measures) 1867 UNTS: The agreement recognises that governments have the right to take sanitary and phytosanitary measures but that they should be applied only to the extent necessary to protect human, animal or plant life or health and should not arbitrarily or unjustifiably discriminate between Members where identical or similar conditions prevail.

\section{${ }^{59}$ Marrakesh Agreement, above n 9, Annex 1A (Agreement on Technical Barrier to Trade) 1867 UNTS}

The Agreement 'seeks to ensure that technical negotiations and standards, as well as testing and certification procedures, do not create unnecessary obstacles to trade. However, it recognizes that countries have the right to establish protection, at levels they consider appropriate, for example for human, animal or plant life or health or the environment, and should not be prevented from taking measures necessary to ensure those levels of protection are met'.

60 Marrakesh Agreement, above n 9, Annex 1C (Trade Related Aspects of Intellectual Property Rights) 1867 UNTS: The agreement recognises that widely varying standards in the protection and enforcement of intellectual property rights and the lack of a multilateral framework of principles, rules and disciplines dealing with international trade in counterfeit goods have been a growing source of tension in international economic relations.

${ }^{61}$ World Trade Orgatization, GATT 1994: Article XX on General Exemptions, $<$ http://www.wto.org/english/tratop_e/envir_e/envir_backgrnd_e/c7s3_e.htm> , at 29 January 2007 
the adoption or enforcement by any contracting party of
measures....62

The exceptions that are relevant to the issue of the environment are covered in article XX (b) and XX (g). While the exception under article $\mathrm{XX}(\mathrm{b})$ is given to a measure that is 'necessary to protect human, animal, or plant life or health', article $\mathrm{XX}(\mathrm{g})$ is limited to measures that 'relat[e] to the conservation of exhaustible natural resources if such measures are made effective in conjunction with restrictions on domestic production and consumption'. ${ }^{63}$

The implementation of these articles is complex, especially to most developing countries that face several problems in using the WTO Dispute Settlement Mechanism effectively. One of the major problems in meeting the objective of this article is its interpretation and application to the cases. It consists of two problems: the first problem is that, as demonstrated in many cases, parties to a dispute must prove that the measure is 'necessary to protect human, plant, or animal life or health' under article XX(b) and 'related to exhaustible natural resources' under article XX(g). Although the GATT panel has consistently applied a similar analysis to both articles, the WTO Appellate Body rectified this by insisting that the two paragraphs should be read based on the ordinary meaning of the texts. ${ }^{64}$ The second problem is, after giving an explanation of the above-mentioned definitions, there is an obligation to give clear explanation whether the measure under point $b$ and $g$ is consistent with the chapeau of article XX of the GATT. ${ }^{65}$ Therefore, given this obligation also requires a clear understanding by the parties to the dispute, the member invoking this article should have an adequate understanding of those complexities.

There are many cases that were decided by the WTO panels or Appellate Body that illustrated the above mentioned complexity. Attention given to environmental issues within the trade legal regime began after the decision by the GATT panel on US-Tuna/Dolphin I that ruled that a US import ban on tuna caught in a manner harmful to dolphins was illegal under the GATT rules. Although the ruling was never adopted, it was reaffirmed by $\mathrm{XX}(\mathrm{g})$.

${ }^{62}$ See General Agreement on Tariffs and Trade, above n 8, article XX.

${ }^{63}$ See General Agreement on Tariffs and Trade, above n 8, article XX, XX(b) and

${ }^{64}$ Hunter, above $\mathrm{n} 71,1193$.

${ }^{65}$ See General Agreement on Tariffs and Trade, above n 8, article XX. 
United States - Restriction on Import of Tuna (US-Tuna/Dolphin II $)^{66}$ which determined the illegality of US import ban under GATT rules.

Article XX(b) of the GATT allows a WTO member to adopt measures that are 'necessary to protect human, plant, or animal life or health'. The interpretation of this article is very complex. This complexity can be seen in the decision of the panels in US-Tuna/Dolphin II. In this case, the panels employed a three-step analysis in interpreting this article. The first step in the analysis is to determine whether the policy, in respect of which these provisions were invoked, falls within the range of policies referred to these provisions, that is policies to protect human, animal or plant life or health. The second step in the analysis is to determine whether the measure is 'necessary' to protect human health, animal or the plant life or health. Finally, it must be determined whether the measure is consistent with the chapeau of article XX, avoiding several conditions, namely arbitrary or unjustifiable discrimination and/or a disguised restriction on international trade. ${ }^{67}$ The next part of essay gives a more detailed explanation of the first two steps.

The main issue of the first step of the analysis was represented by the argument of the European Economic Community (EEC) which contended that Article XX (b) could not justify measures taken by the US to protect living things located outside the territorial jurisdiction of the party taking the measure. This argument was rejected by the US. In responding to this argument, the panel observed several considerations, inter alia, the chapeau of article XX of GATT and general international law. In regard to the chapeau, the panel noted that "the conditions set out in the text of Article XX (b) and the preamble qualify only the trade measure requiring justification ("necessary to") or the manner in which the trade measure is applied ("arbitrary or unjustifiable discrimination", "disguised restriction on international trade"), ${ }^{68}$ Furthermore, in regard to general international law, the panel noted that 'states are not in principle barred from regulating the conduct of their nationals with respect to persons, animals, plants and natural resources outside of their territory'. ${ }^{69}$ Having observed these considerations,

66 United States - Restriction on Import of Tuna, Panel report Doc. DS 29/R, circulated at 16 June 1994 (unadopted), (US - Tuna/Dolphin II), <http://www.worldtradelaw.net/reports/gattpanels/tunadolphinII.pdf>, at 10 January 2007.

${ }^{67}$ Ibid., par 5.29.

${ }^{68}$ Ibid., par 5.31.

${ }^{69}$ Ibid., par 5.32. 
' $[t]$ he Panel therefore found that the policy to protect the life and health of dolphins in the eastern tropical Pacific Ocean, which the United States pursued within its jurisdiction over its nationals and vessels, fell within the range of policies covered by Article XX (b) ${ }^{70}$

In addition, the first analysis involves the linkage between public health and environment. The linkage can readily be seen in areas such as air and water quality, food safety, epidemic diseases and safety in the workplace. ${ }^{71}$ The link between environmental conditions and violation of the right to health is illustrated in some communications received by the Human Rights Committee. The communication 'exemplify[s] the irreversible impacts on health of large-scale industrial accidents as well as the deleterious effects of other less spectacular sources of pollution, such as the continuous discharge of toxic and hazardous substances into air, soil, and water'. ${ }^{72}$ The right to health is an inclusive right extending not only to timely and appropriate health care but also to the underlying determinants of health, inter alia, environmental conditions. ${ }^{73}$

In regard to the second step of the analysis, in this case, the panel gave the interpretation of the term 'necessary'. Particularly, whether under Article XX (b) measures necessary to protect the life or health of animals could include measures taken so as to force other countries to change their policies within their own jurisdictions, and requiring such changes in order to be effective. ${ }^{74}$ In this case, The US interpreted it simply as 'needed' whereas the EEC interpreted it as 'indispensable' or 'unavoidable'. ${ }^{75}$ However, the panel

${ }^{70}$ Ibid., par 5.33.

${ }^{71}$ Nathalie Bernasconi-Osterwalder, above n 71, 81 .

${ }^{72}$ Fatma Zohra Ksentini, Special Rapporteur, Review of Further Developments in Fields with Which the Sub-Commission has been concerned Human Rights and the Environment, E/CN.4/Sub.2/1994/9, 6 July 1994.

${ }^{73}$ General comment No. 14 the right to the Highest Attainable Standard of Health, E/C.12/2000/4 of the Economic and Social Council. More specifically, the convention also mentioned that state parties, to achieve the full realization of the right to health, shall take necessary steps, inter alia, 'the improvement of all aspects of environmental and industrial hygiene'. It comprises 'the requirement to ensure an adequate supply of safe and potable water and basic sanitation; the prevention and reduction of the population's exposure to harmful substances such as radiation and harmful chemicals or other detrimental environmental conditions that directly or indirectly impact upon human health'.

${ }^{74}$ See US - Tuna/Dolphin II, above n 95, par 5.38.

${ }^{75}$ See US-Tuna/Dolphin II, above n 95, par 5.34. 
considered that a measure must be 'among the measures reasonably available..., that will entail the least degree of inconsistency with the other GATT provisions'. ${ }^{76}$ This consideration was based on the 1972 Marine Mammal Protection $\mathrm{Act}^{77}$ that required harvesting nations to adopt the regulatory program governing the incidental taking of marine mammals in the course of harvesting that is comparable to that of the United States. ${ }^{78}$ They found that the objectives of the General Agreement would be seriously impaired if contracting parties imposed trade embargoes so as to force other countries to change their policies within their jurisdiction. ${ }^{79}$ The Panel accordingly found that the import prohibitions on tuna and tuna products maintained by the United States were inconsistent with Article XI:1 of the GATT and were not justified by Article XX (b) ${ }^{80}$

The interpretation of the term 'necessary' was also analyzed in other cases: Thailand - Restriction on Importation of and Internal Taxes on Cigarettes (Thailand - Cigarettes) ${ }^{81}$ and more recently European Communities - Measures Affecting Asbestos and Products Containing Asbestos (EC - Asbestos). ${ }^{82}$ In the former case the panel concluded, given other measures 'were reasonably available to Thailand to control the quality and the quantity of cigarettes smoked...', Thailand's practice of permitting the sale of domestic cigarettes while not permitting the importation of foreign cigarettes was not 'necessary' within the meaning of article $\mathrm{XX}(\mathrm{b}) .{ }^{83}$ In the latter case, the Appellate Body concluded that a French ban on the manufacturing, sale, and importation of asbestos fibers was justified under

${ }^{76}$ See US - Tuna/Dolphin II, above n 95, par 5.35.

${ }^{77}$ The Marine Mammal Protection Act of 1972, PL 92-522, 86 Stat 1027.

${ }^{78} \mathrm{Ibid}$, article 101(a)(2)(I).

${ }^{79}$ See US - Tuna/Dolphin II, above n 95, par 5.38.

${ }^{80}$ See US - Tuna/Dolphin II, above n 95, par 5.39.

${ }^{81}$ Thailand - Restriction on Importation of and Internal Taxes on Cigarettes, GATT Doc. DS 10/R-37S/200, adopted 7 November 1990, (Thailand - Cigarettes), $<$ http://www.worldtradelaw.net/reports/gattpanels/thaicigarettes.pdf>, 12 January 2007.

${ }^{82}$ European Communities - Measures Affecting Asbestos and Products Containing Asbestos, Appellate Body report (WT/DS135/AB/R), adopted 12 March 2001, (EC Asbestos). <http://www.worldtradelaw.net/reports/wtoab/ec-asbestos(ab).pdf >, at 12 January 2007.

${ }^{83}$ See Thailand-Cigarettes, above n 113, par. 81. 
article $\mathrm{XX}(\mathrm{b})$. They emphasized that the objective of the measure - the preservation of human life and health - was indeed 'both vital and important in the highest degree' which means that no other measures were reasonably available. $^{84}$ This case was the first case that accepted the defense from a WTO member under article XX(b).

Furthermore, the application of Article XX(g) of the GATT also involves complex interpretations. The term 'exhaustible natural resources' consists of biological resources such as fish stocks or endangered turtles. For example, the panels in US - Tuna and Tuna Product from Canada ${ }^{85}$ and Canada-Unprocessed Herring and Salmon ${ }^{86}$, concluded that the natures of fish stocks are exhaustible natural resources. ${ }^{87}$ Moreover, the term also includes non-living resources such as clean air. In US - Standard for Reformulated Gasoline and Conventional Gasoline ${ }^{88}$, Venezuela doubted that clean air was an 'exhaustible natural resources' by considering that "clean air was a "condition" of air that was renewable rather than a resource that was exhaustible... ${ }^{89}$ The panel disagreed with this argument and determined that clean air is a resource, is natural, and can be depleted..$^{90}$ In

${ }^{84}$ See EC - Asbestos, above n 114, par 172, <http://www.worldtradelaw.net/ reports/wtoab/ec-asbestos(ab).pdf>, at 12 January 2007.

${ }^{85}$ US - Tuna and Tuna Product from Canada, Panel Report (L/5198 - 29S/91) adopted 22 February 1982, <http://www.worldtradelaw.net/reports/gattpanels/ustuna.pdf>, at 12 January 2007.

${ }^{86}$ Canada-Measures Affecting Export of Unprocessed Herring and Salmon, Panel Report (L/6268 - 355/98) adopted at 22 March 1998, par 2.3. In this case, the US brought a complaint against Canada, Stating that Canadian Laws and regulations restricting export from Canada of unprocessed sockey salmon, pink salmon, and herring were inconsistent with the obligations of Canada pursuant to article XI of the GATT, and that article XX exceptions did not justify any of those regulations.

${ }^{87}$ See US - Tuna and Tuna Product from Canada, above n 117, par 4.9. In this Paragraph, the panel noted that 'both parties considered tuna stocks, including albacone tuna, to be an exhaustible natural resource in need of conservation management', and See CanadaUnprocessed Herring and Salmon, above n, par 4.4. In this paragraph panel 'agreed with the parties that salmon and herring stocks are 'exhaustible natural resources'.

${ }^{88}$ US - Standard for Reformulated Gasoline and Conventional Gasoline, Panel Report (WT/DS2/AB/R), adopted 29 January 1996, (US - Reformulated Gasoline), $<$ http://www.law.georgetown.edu/iiel/cases/US-Gasoline(panel).doc>, at 13 January 2007.

${ }^{89}$ Ibid., par 3.60.

${ }^{90}$ Ibid., par 6.37 . 
other cases, the term has been interpreted by the panels and Appellate Body to include living, renewable and non-renewable resources. ${ }^{91}$

In interpreting this term, the relation between MEAs and international trade can also be illustrated in several cases brought to WTO dispute settlement. The panels have different approaches in addressing this issue. In US - Tuna/Dolphin II, the panel disagreed with the European Economic Community (EEC) which argued that dolphins could not be considered as natural resource on the ground that CITES ensured that there was no trade in dolphin species. Consequently, the panel concluded that dolphins qualified as natural resources. On the other hand, in United States - Import Prohibition of Shrimp and Shrimp Products (US - Shrimp/Turtle I), ${ }^{92}$ the Appellate Body showed their favor to consider MEAs in interpreting the term. In responding to Pakistan and Thailand, which argued that exhaustible natural resources referred to finite resources such as minerals rather than biological or renewable resources, the Appellate Body argued that if the all natural resources were considered to be exhaustible, the term exhaustible would became 'superfluous'. ${ }^{93}$ With this interpretation the Appellate Body pointed out that the words in article $\mathrm{XX}(\mathrm{g})$ 'must be read by a treaty interpreter in the light of the contemporary concerns of the community of nations about the protection and conservation of the environment ${ }^{94}$ The Appellate Body further referred to MEAs such as CITES, CBD, and UN Convention of the Law of the Sea as well as to the opinion of environmental experts in determining whether turtles were exhaustible. ${ }^{95}$

Beside the interpretation of the term 'exhaustible natural resources', article $\mathrm{XX}(\mathrm{g})$ is also concerned with the interpretation of the term 'relating

${ }^{91}$ Nathalie Bernasconi-Osterwalder, above n 77, 79.

92 United States - Import Prohibition of Shrimp and Shrimp Products, Appellate Body Report (WT/DS58/R/AB) adopted 12 October 1998, (US - Shrimp/Turtle I), $<$ http://www. law.georgetown.edu/iiel/cases/US-Shrimp(abr)(ab).pdf $>$, accesed at 14 January 2007.

${ }^{93}$ Nathalie Bernasconi-Osterwalder, above n 77, 79. In the US - Shrimp/Turtle I, The Appellate Body dealt with these arguments with the following statement: 'One lesson that modern biological sciences teach us is that living species, though in principle, capable of reproduction and, in that sense, 'renewable', and in certain circumstances indeed susceptible of depletion, exhaustions and extinction, frequently because of human activities. Living resources are just as 'finite' as petroleum, iron, and other non-living resources.

\footnotetext{
${ }^{94}$ See US - Shrimp/Turtle I, above n 124, par. 129.

${ }^{95}$ See US-Shrimp/Turtle I, above n 124, par. 132-133.
} 
to' with regard to the conservation of exhaustible natural resources and the term 'in conjunction with' with regard to restrictions on domestic production and consumption. The GATT panels have interpreted these terms differently in several cases since the pre-WTO era and up until now. For example, in Canada - Unprocessed Herring and Salmon, the panel concluded that the term 'relating to' means that a measure must be 'primarily aimed at the conservation of exhaustible natural resources' and 'in conjunction with' means that a measure must be 'primarily aimed at rendering effective the domestic production restrictions'. ${ }^{96}$ The panel held that Canada had failed to prove that the export restrictions met the above meaning. On the other hand, in US - Reformulated Gasoline, the Appellate Body acknowledged that 'the phrase "primarily aimed at" is not itself treaty language and was not designed as a simple litmus test for inclusion or exclusion from Article XX $(\mathrm{g})^{3} \cdot{ }^{97}$ The Appellate Body then considered 'primarily aimed at' the same as 'substantial relationship'. ${ }^{98}$ The Appellate Body in the US - Shrimp/Turtle case upholding this interpretation by arguing the relationship between the Environmental Protection Agency (EPA) baseline establishment rules and the conservation of clean air in the United States is 'a close and genuine relationship of ends and means'. ${ }^{99}$

Some of the important terms that the member countries should prove to justify their measures under article $\mathrm{XX}(\mathrm{b})$ and $\mathrm{XX}(\mathrm{g})$ were mentioned above. Furthermore, a member invoking article XX of GATT should ensure that the measure, after proving that the measure is covered under article $\mathrm{XX}$ (b) and/or XX(g), does not constitute 'arbitrary or unjustifiable discrimination in countries when the same condition are prevail' or ' $a$ disguised restriction on international trade'. The Appellate Body noted in US - Reformulated Gasoline that the chapeau, by its express terms, not so much questions the measure or its specific contents as such, but rather the manner

${ }^{96}$ See Canada-Unprocessed Herring and Salmon, above n 118, par 4.6.

${ }^{97}$ US - Standard for the Reformulated and Conventional Gasoline, Report of the Appellate Body (WT/DS2/AB/R), 29 April 1996, p 19. <http://www.worldtradelaw.net/ reports/wtoab/us-gasoline(ab).pdf $>$, accesed at 25 January 2007.

${ }^{98}$ In relation to this the $\mathrm{AB}$ noted that '[t]he relationship between the baseline establishment rules and the "non-degradation" requirements of the Gasoline Rule is not negated by the inconsistency, found by the Panel, of the baseline establishment rules with the terms of Article III:4'. They further considered that, 'given that substantial relationship, the baseline establishment rules cannot be regarded as merely incidentally or inadvertently aimed at the conservation of clean air in the United States for the purposes of Article XX $(\mathrm{g})$ '.

${ }^{99}$ See US-Shrimp/Turtle I, above n 124, par. 136- 137. 
in which that measure is applied. Pursuant to the chapeau of Article XX, a measure may discriminate, but not in an "arbitrary" or "unjustifiable" manner. ${ }^{100}$

In US - Shrimp/Turtle I, the Appellate Body adopted a more balanced approach compared with US - Reformulated Gasoline case ${ }^{101}$ Although the US import ban was related to the conservation of exhaustible natural resources, it could not be justified under Article XX because the ban constituted 'arbitrary and unjustifiable' discrimination under the chapeau of Article XX. ${ }^{102}$ In reaching this conclusion, the Appellate Body pointed out that, inter alia, in its application the measure was 'unjustifiably' discriminatory because of its intended and actual coercive effect on the specific policy decisions made by foreign governments that were Members of the WTO. ${ }^{103}$ The Appellate Body also concluded that the measure constituted 'arbitrary' discrimination because of the rigidity and inflexibility in its application, and the lack of transparency and procedural fairness in the administration of trade regulations. ${ }^{104}$ Based on this decision, the US issued a new guideline that is essentially flexible enough in granting a certificate to the exporting countries. ${ }^{105}$ Malaysia brought an action under article 21.5 of the Dispute Settlement Understanding, contending that the guideline revision did result in 'unjustifiable or arbitrary discrimination' as the compliance with policies and standards were unilaterally decided by the US. ${ }^{106}$ However, the 129, p. 22.

${ }^{100}$ See US - Standard for the Reformulated and Conventional Gasoline, above n

${ }^{101}$ Goyal, above n 4, 169.

${ }^{102}$ See US - Shrimp/Turtle I, above n 124, par. 129.

${ }^{103}$ World Trade Organization, 'US - Shrimp I: Summary of the Key Finding', at $<$ http://www.wto.org/english/tratop_e/dispu_e/cases_e/lpagesum_e/ds58sum_e.pdf $>$, viewed at 27 January 2007.

${ }^{104}$ Ibid.

${ }^{105}$ See United States - Import Prohibition of Shrimp and Shrimp Products, above n 21, par 119. 'The United States had adopted a cooperative approach with WTO Members from the Caribbean/Western Atlantic region, with whom it had concluded a multilateral agreement on the protection and conservation of sea turtles, namely the Inter-American Convention. Yet the United States had not, we found, pursued the negotiation of such a multilateral agreement with other exporting Members, including Malaysia and the other complaining WTO Members in that case'.

21, par 135 .

${ }^{106}$ See United States - Import Prohibition of Shrimp and Shrimp Products, above n 
Appellate body considered that "the new measure is more flexible than the original measure and has been applied more flexibly than was the original measure' and held that the measure did not meet the requirements of the chapeau of Article XX relating to arbitrary or unjustifiable discrimination. ${ }^{107}$

The understanding of the above legal issues is essential for Indonesian lawyers representing their country in WTO dispute on trade and environment issues. The next part of the essay discusses how those various legal issues should be emphasized in the capacity building program so that Indonesia able to defend and protect their position in the WTO Dispute Settlement Mechanism on trade and environment issues effectively.

\section{Capacity Building for Indonesia in Dispute Settlement Mechanism on Trade \& Environment Cases}

This essay takes Indonesia as an example of developing countries and a member of the WTO. The importance of the WTO Dispute Settlement Mechanism has recently been increased for the protection Indonesian's trade. Hassan Kartadjoemena precisely points the increased importance of WTO rules for Indonesia by arguing, 'the GATT-WTO rules became important as Indonesia made the policy decision boost non-oil exports and to become more trade oriented with a view of accelerating its growth through exports' ${ }^{108}$ The Minister of Trade of the Republic of Indonesia also points out the significance of this system by saying:

'Why is a multilateral trading system still optimal? It is because our bargaining position is best defended and we are able to enjoy market access and opening up to the whole world rather than just one country or region, and thus much greater benefits. Other than that it is still the best system to ensure "fair trade", 21 , par 140 .

${ }^{107}$ See United States - Import Prohibition of Shrimp and Shrimp Products, above n

${ }^{108}$ Hassan S. Kartadjoemena, Capacity Building for Dispute Settlement in the WTO: A Preliminary Note of the Case of Indonesia, (paper presented at the Asia Dialogue on WTO Dispute Settlement and Sustainable Development, Indonesia, 25-26 January 2006, 1. (He is former Indonesian Ambassador to the GATT/WTO). 
that is if Indonesia faces any unfair trade practices, we can take to the dispute settlement under the WTO'. ${ }^{109}$

Although Indonesia shows commitment to the WTO Dispute Settlement Mechanism, this commitment is still likely to face the problems as many other developing countries do. These problems are, as has already discussed, the lack of legal capacity, the lack of institutional capacity, and the fear of retaliation from developed countries. Among these three problems, the lack of legal capacity is the biggest challenge for the country.

One of the problems concerning the lack of legal capacity for Indonesia is the relative lack of resources and structural incentives for the utilization of the WTO law. This condition has been causing Indonesia not to utilize the WTO Dispute Settlement Mechanism so often. This relative lack of the usage of this mechanism causes them not to prioritize the training of their internal lawyers, which makes it unavoidable to hire international legal counsels who have better legal understanding and experience.

In addition, it is impossible to grasp the overall structure which is making it difficult for Indonesia to effectively utilize the WTO Dispute Settlement Mechanism without considering the overall process of dealing with the entirety of WTO legal issues. There might still be difficulties in understanding and following the development of WTO law. ${ }^{110}$ An example is the implementation of the Trade-Related Aspects of Intellectual Property Rights (TRIPs) Agreement in Indonesia. The main obstacle for the implementation of TRIPs is the lack of enforcement of related laws. This enforcement is difficult and complex since it should also be supported by educating general public about the meaning, function, and the role of intellectual property rights and by ensuring effective bureaucracy and independence of judiciary. These problems show the necessity for the current Indonesian capacity building program to enhance the understanding on the WTO law and the ability to defend through the Dispute Settlement Mechanism.

Two cases under WTO Dispute Settlement Mechanism are good examples to show what types of capacity building program on WTO law is necessary for Indonesia. The two cases are Indonesia - Certain Measure

${ }^{109}$ Mari Pangestu, Indonesia, International Trade Negotiations and Fair Trade, The Keynote Address by Minister of Trade of the Republic of Indonesia at the WTO Forum Third Anniversary, Jakarta, 2 February 2006.

110 Above n 107, 'Capacity Building for Dispute Settlement in the WTO: A Preliminary Note of the Case of Indonesia', 5. 
Affecting the Automobile Industry and Korea - Anti-Dumping Duties on Imports of Certain Paper from Indonesia. ${ }^{11}$ Although these cases were on purely trade matters without any environmental implication, the understanding of the relevant laws and Indonesia's legal arguments in those cases is helpful for identifying what areas of legal issues need improvement also in trade and environment issues.

In the first case, the United States, Japan, and the European Union claimed that the measure taken by Indonesia - provision of tax and custom duty - benefited the National Cars produced in Korea, but did not provide similar benefits to like-products of companies from the complaining parties. In other words, they claimed that Indonesia violated MFN principle under article I of the GATT. ${ }^{112}$ The complaining parties also claimed that another measure - custom duty benefits for certain parts and components of the National Cars production - violated article III of the GATT. ${ }^{113}$ The Panel agreed with the argument of the complaining parties.

The second case is one where Indonesian became as main complainant under the DSU for the first time. In this case, Korea imposed anti-dumping duties to Indonesian paper products. ${ }^{114}$ Indonesia gave a quite comprehensive legal argument, inter alia, regarding the violation of article I, VI, and Annex II of Anti Dumping Agreement. ${ }^{115}$ Based on the legal claim, the Panel found

${ }^{111}$ Indonesia - Certain Measure Affecting the Automobile Industry, (WT/DS54/15), 7 December 1998; Korea-Anti-Dumping Duties on Imports of Certain Paper from Indonesia, Panel Report (WT/DS312/R), adopted by 28 October 2005.

$<$ http://www.worldtradelaw.net/reports/wtopanels/korea-paperad(panel).pdf>, last accessed on 25 January 2007).

${ }^{112}$ Nathalie Bernasconi-Osterwalder, above n 77, 57.

${ }^{113}$ Nathalie Bernasconi-Osterwalder, above n 77, 57.

114 There were sixteen types of products that were categorized as "uncoated paper and paperboard used for writing, printing or other graphic purposes" and "carbon paper, selfcopy paper and other copying or transfer papers".

${ }^{115}$ World Trade Organization, Korea - Anti-Dumping Duties on Imports of Certain Paper from Indonesia, <http://www.wto.org/english/tratop_e/dispu_e/cases_e/ds312_e.htm>, last accessed on 25 January 2007. According to the request for consultations from Indonesia, Korea violates its WTO obligations in respect of the following aspects: (1) Korea's initiation of investigation, notwithstanding several deficiencies such as the applicants' failure to include in the application sufficient and adequate evidence of dumping, injury and causal link; (2) Korea's failure to provide in the Notice of Initiation any information regarding the factors on which the allegation of injury was based, (3) the way Korea granted confidential treatment to information contained in the application, (4) Korea's making of a request for information from a firm not subject to investigation, without having obtained the agreement of that firm and 
that Korea, vis a vis, the Korean investigating authority, did not act consistently with, inter alia, article II.2 and VI.8 and Annex II(3) concerning 'normal value calculation', and article VI.8 and Annex II(7) concerning 'dumping margin determination'. ${ }^{116}$

Indonesia's legal arguments in the second case demonstrated an understanding of the WTO law, especially on whether the measures taken by Korea fall within a particular term in an article of the agreement. For example, Indonesia argued that the measure did not meet the circumstances required under Article VI.8. ${ }^{117}$ inter alia, provision of "necessary information (or refusal of access to necessary information) within a reasonable period of time'. ${ }^{118}$ Indonesia also argued that the Korean argument regarding 'like products' did not fall within the meaning of the agreement. ${ }^{119}$ In addition, the argument also cited some of the WTO jurisprudence in anti-dumping related cases.

Although the lesson from these cases may be limited because the number of case studies here is small, some arguments given by Indonesia, especially in the case of Korea-Anti-Dumping Duties on Imports of Certain

having notified the Indonesian Government of such request, (5) Korea's rejection of information related to the sales of a certain firm, without explaining the reason,(6) Korea's preliminary determination, in such respects as: like products, constructed value, best information available, denial of access to information, and the refusal to provide an opportunity to the exporters to present their views; (7) Korea's final determination, in such respects as: like products, individual dumping margins, constructed value, treating a certain firm and other firms as a single economic unit; the impact and effect of the dumped imports on the domestic industry and prices in the domestic market, failure to evaluate all relevant economic factors and indices, and denial of access to information.

Accordingly, Indonesia considers that these Korean measures are inconsistent with: Article VI of GATT 1994, inter alia, Article VI:1, VI:2 and VI:6; Articles 1, 2.1, 2.2, 2.2.1.1, 2.2.2, 2.4, 2.6, 3.1, 3.2, 3.4, 3.5, 4.1(i), 5.2, 5.3, 5.4, 5.7, 6.1.2, 6.2, 6.4, 6.5, 6.5.1, 6.5.2, 6.7, 6.8. 6.10, 9.3, 12.1.1(iv), 12.2, 12.3, Annex I, and paragraphs 3, 6, and 7 of Annex II of the Anti-Dumping Agreement.

${ }^{116}$ World Trade Organization, 'Summary of the key finding of the case: Korea Anti-Dumping Duties on Imports of Certain Paper from Indonesia', <http://www.wto.org/ english/tratop_e/dispu_e/cases_e/lpagesum_e/ds312sum_e.pdf $>$, last accessed on 25 January 2007).

${ }^{117}$ Marrakesh Agreement, above n 9, Annex 1A (Agreement on Implementation of Article VI of the General Agreement on Tariffs and Trade 19941867 UNTS.

${ }^{118}$ See Korea-Anti-Dumping Duties on Imports of Certain Paper from Indonesia, above n 143, par 4.10.

${ }^{119}$ See Korea - Anti-Dumping Duties on Imports of Certain Paper from Indonesia, above n 143, par $4.25-4.26$. 
Paper from Indonesia, show the ability of its human resources to interpret the WTO law and to utilize the WTO jurisprudence as a basis for legal arguments. However, it requires a long-term capacity building program, which especially makes it possible to follow the development of law and cases in various issues under the WTO.

The need to have such capacity building program is also the case for issues on trade and environment. In this particular concern, the capacity building program should include a program to ensure the understanding of the WTO law as well as its jurisprudence. Particularly, article XX of the GATT. Based on the analysis in the previous part of this essay argue that the program should emphasize on two major aspects. The first aspect is the interpretation of several terms such as 'necessary' under article $\mathrm{XX}(\mathrm{b})$, 'relating to' and 'exhaustible natural resources' under article $\mathrm{XX}(\mathrm{g})$, and 'arbitrary or unjustifiable discrimination' under the chapeau of article XX. There are several cases that are discussed in previous part of this essay explaining how the term 'necessary' under article XX(b) should be interpreted. There are US - Tuna/Dolphin I, Thailand-Cigarettes and more recently EC - Asbestos. In these cases, The WTO Panel and Appellate Body determined whether the measures at stake were among the measures available that would entail the least degree of inconsistence with the GATT provisions. There are also several cases that discuss the term 'relating to' under article $\mathrm{XX}(\mathrm{g})$ should be interpreted such as Canada - Unprocessed Herring and Salmon, US - Reformulated Gasoline, and US - Shrimp/Turtle. It is interesting to learn the different approaches used by the Panel and Appellate Body in interpreting this term in those cases.

The second aspect is the ability to prove whether the measure, if it is believed fall within the article $\mathrm{XX}(\mathrm{b})$ or $\mathrm{XX}(\mathrm{g})$, is consistent or not with the chapeau of article XX. In the US - Shrimp/Turtle I and the US Reformulated Gasoline, several issues such as the rigidity and flexibility of the application of the measure, transparency, and unilateral measures were balanced by the Appellate Body in determining whether the measures were arbitrary or unjustifiable discrimination under the chapeau of article XX. The discussion of the above two aspects should also refer to the ongoing development in both law and cases.

Beside the understanding of the article XX of the GATT, it is also important that the program consist of effort to increase the understanding of human resources on Multilateral environmental agreement that relate to trade, especially its main principle that can help Indonesia give a more comprehensive argument to a particular case. The understanding of MEAs might help Indonesia give the more holistic argument/interpretation on the impact of trade to the environment. There are some decisions of the WTO 
panel and Appellate Body that relied on MEAs in interpreting the article XX. In the previous part of the essay, the decision is explained in US Shrimp/Turtle. Moreover, given the use of trade-related measures to protect the environment and human health under the WTO framework is likely be adopted by developing countries which have adequate environmental standards and protections, it is also important to have a clear understanding some of the principles of these environmental standards and protections in countries like the US and EC.

Understanding on article $\mathrm{XX}$ and MEAs is essential for Indonesian Capacity Building Program, however, it should be supported by understanding of some of GATT general principles such as most-favourednation principle and national treatment principle. Recently, the discussion between national treatment principle and the concept of 'like products' has become one of the primary issues in the context of trade and environment. 'When products are considered 'like', one product generally may not be treated more favorably than the other. If products are not considered 'like', members may treat the differently'. ${ }^{120}$ Therefore, within the framework of long-term capacity building programs, a comprehensive understanding of the WTO law in trade and environment related issues should be based on the collaboration and coordination between various agencies, particularly, between Department of Trade and Ministry of Environment.

The capacity building program on trade and environment issues should also consider the cooperation with other developing countries which might face a similar challenges and interests. Indonesia needs to obtain international financing and capacity building programs to develop a joint cooperation with other developing countries. The objective of this cooperation is to analyze trade policies from industrial countries that relate to their interests of those can lower their costs. This cooperation might support Indonesia in developing cost-effective mechanisms to recognize the possible impact on the prospects of their trade, identify the responsible authorities and individuals in addressing the issue, and gather all the resources together to bring a legal claim. ${ }^{121}$

Outside the WTO forum, the increased capacity of the Indonesian's human resources on trade and environment related aspects, would also be

${ }^{120}$ Nathalie Bernasconi-Osterwalder, above n 77, 2-3.

121 Gregory Shaffer, "The challenge of WTO Law: Strategies for Developing Country Adaptation", (World Trade Review, 2006), p. 5:2, 177, 179. He mentioned that developing countries should have this mechanism to avoid negative impact of trade-related measures. 
needed to develop a comprehensive environmental provisions in its Free Trade Agreement (FTA) as well as its implementation. A comprehensive environmental provisions should includes, inter alia, mandatory requirements that countries provide for high levels of environmental protection, continuously improve their environmental standards, and not weaken or derogate from their environmental laws. Such requirements should be subject to enforceable dispute resolution. In addition, all the parties to a trade agreement should agree to comply with and fully and effectively implement, including through domestic legislation and mechanisms for citizen enforcement in domestic law, the obligations under international environmental agreements to which they are a party. The current Indonesian's Economic Partnership Agreement (EPA) with Japan as well as the ASEAN - China FTA do not contain comprehensive provisions on the environmental protection. Indonesia's next FTAs, no doubt, should ensure that the provisions be included, of those require the capacity of its human resources to negotiate that provisions in the development of the agreements.

Finally, the increased capacity of its human resources on trade and environment related aspects, would no doubt be needed so that Indonesia can effectively join the current global efforts and initiatives in addressing climate change trough both mitigation and adaptation strategies.

\section{Conclusion}

Developing countries represent a greater proportion of the total membership of the WTO members. The objective of their involvement in the WTO is to gain the benefit of international trade that is to promote their major trade interests. Accordingly, the Dispute Settlement Mechanism has become a vital instrument to protect them from the protectionist practice of their counterpart. However, developing countries face several problems in using the Dispute Settlement Mechanism effectively. It consists of three major problems - lack of understanding of WTO law and its jurisprudences, lack of institutional capacity, and the fear of retaliation from developed countries when bringing the claim against developed countries to Dispute Settlement Mechanism. Indonesia, as one of developing countries also faces the above three problems. In order to prepare Indonesia to use the Dispute Settlement Mechanism effectively, it needs to conduct capacity building program for its human resources.

One of the important topics in this international trade is the relationship between trade and environment - the use of trade-related measure to protect the environment and human health. The essay focuses on 
capacity building programs that deal with trade and environment dispute under the WTO. In the trade and environment dispute, article XX of the GATT give a basis for the use of trade-related measure to protect the environment and human health. In the implementation of this article, there are many cases decided by the WTO Panels and the WTO Appellate Body involving developing countries. Therefore, in the Indonesian context, the capacity building program in Indonesia on the Dispute Settlement Mechanism on trade and environment issue should emphasize a program that would enhance the Indonesian's human resources understanding the implementation of article XX of the GATT, especially paragraph $\mathrm{b}$ and $\mathrm{g}$.

In addition, the adequate understanding of Indonesia human resources in dealing with those particular legal issues would finally became a basis for them to understand other WTO Agreements that specifically address or relate to the environmental aspects such as TRIPs Agreement, TBT Agreement, and SPS Agreement. In addition, it should be noted that the ability to use Dispute Settlement Mechanism effectively in trade and environment case might be determined by the understanding other trade-related issues that might interrelate to one another. The capacity building program, to be successful should be designed and implemented within the framework of the long-term programs that also cover the program to deal with two other problems that developing countries have - lack of institutional capacity and fear of retaliation from developed countries. 


\section{Bibliography}

\section{Books/Journals/Articles}

Bernasconi, Nathalie-Osterwalder (et al), Environment and Trade, 2005.

Bernasconi, Nathalie-Osterwalder, WTO's contribution to sustainable development governance: Balancing Opportunities and Threats, (paper presented at WTO's Contribution to Sustainable Development Governance: Balancing the Opportunities and Threats Conference, Paris, $20 \& 21$ October 2005).

Busch L. March, The WTO Dispute Settlement Mechanism and Developing Countries, Trade Brief on WTO and Dispute Settlement, 2004.

Delich, Valentina, Developing Countries and the WTO Dispute Settlement System, in Bernard Hoekman (ed) et al, Development, Trade, and the WTO: A Hand Book, 2002.

Goyal, Anupal, The WTO and International Environmental Law: Toward Reconciliation, 2006.

Hoekman, Bernard M. and Kostecki M. Michel, The Political Economy of the World Trading System: The WTO and Beyond, $2^{\text {nd }}$ ed, 2001.

International Institute for Sustainable Development and United Nation Environmental Program, $2^{\text {nd }}$ ed, Environment and trade: A Handbook, 2005.

Hunter, David, et al, International Environmental Law \& Policy, $2^{\text {nd }}$ ed, 2002.

Kartadjoemena S. Hassan, Capacity Building for Dispute Settlement in the WTO: A Preliminary Note of the Case of Indonesia, (paper presented at the Asia Dialogue on WTO Dispute Settlement and Sustainable Development), Indonesia, 25-26 January 2006.

Pangestu, Mari, 'Indonesia, International Trade Negotiations and Fair Trade', The Keynote Address by Minister of Trade of the Republic of Indonesia at the WTO Forum Third Anniversary, Jakarta, 2 February 2006.

Shaffer, Gregory, The challenge of WTO Law: Strategies for Developing Country Adaptation, World Trade Review, 5:2, 2006. 
Shaffer, Gregory, How to Make the WTO Dispute Settlement System Work for Developing Countries: Some Proactive Developing Countries, ICTSD Resource Paper, 5, 2003.

Stiglitz E.Joseph and Charlton, Andrew, Fair Trade For All: How Trade Can Promote Development, 2006.

\section{Report}

Ksentini, Fatma Zohra, Special Rapporteur, Review of Further Developments in Fields with Which the Sub-Commission has been concerned Human Rights and the Environment, E/CN.4/Sub.2/1994/9, 6 July 1994.

General comment No. 14 the right to the Highest Attainable Standard of Health, E/C.12/2000/4 of the Economic and Social Council.

Millennium Ecosystem Assessment Global Assessment Report: Current State and Trends, 2005.

Summary of the policy makers of the Working Group I to the Fourth Assessment Report of the Intergovernmental Panel on Climate Change, 2007.

\section{Legislation/Treaty}

Marrakesh Agreement Establishing the World Trade Organization, opened for signature 15 April 1994, 1867 UNTS, (entered into force 1 January 1995).

Marrakesh Agreement, Annex 1B (General Agreement on Trade in Services) 1869 UNTS 183.

Marrakesh Agreement, Annex 1A (Agreement on the Application of Sanitary and Phytosanitary Measures) 1867 UNTS.

Marrakesh Agreement, Annex 1A (Agreement on Technical Barrier to Trade) 1867 UNTS

Marrakesh Agreement, Annex 1C (Trade Related Aspects of Intellectual Property Rights) 1867 UNTS

Marrakesh Agreement, Annex 2, (Understanding of Rules and Procedures Governing the Settlement of Disputes).

The United Nation Charter, article 1.3. 
The Convention on International Trade in Endanger Species, 12 I.L.M. 1085(1973); 993 U.N.T.S. 243, Signed on March 3, 1973, entered into forced July 1, 1975.

Vienna Convention for the Protection of the Ozone Layer, UNEP Doc. IG.53/5; 26 I.L.M. 1529 (1987), signed on March 22, 1985, entered into forced September 22, 1988.

Basel Convention on the Control of Transboundary Movements of Hazardous Wastes and Their Disposal, 28 I.L.M. 657 (1989), signed on March 22, 1989, entered into force May 5, 1992.

Convention on Biological Diversity, 31 I.L.M. 818 (1992), signed on June 5, 1992, entered into force December 29, 1993.

The Cartagena Protocol on Biosafety, signed on January 29, 2000, entered into force September 11, 2003.

United Nations Framework Convention on Climate Change, 31 I.L.M. 849 (1992), signed on May 29, 1992, entered into force March 21, 1994.

Kyoto Protocol to the United Nations Framework Convention on Climate Change, FCCC/CP/1997/L.7/add.1, signed on December 11, 1997, entered into force February 16, 2005.

The Marine Mammal Protection Act of 1972, PL 92-522, 86 Stat 1027.

\section{WTO Panels Report/Appellate Body Report}

Indonesia - Certain Measure Affecting the Automobile Industry, (WT/DS54/15), 7 December 1998.

European Communities - Measures Affecting Asbestos and Products Containing Asbestos, Appellate Body report (WT/DS135/AB/R), adopted 12 March 2001, (EC - Asbestos).

Korea - Anti-Dumping Duties on Imports of Certain Paper from Indonesia, Panel Report (WT/DS312/R), adopted by 28 October 2005.

Thailand - Restriction on Importation of and Internal Taxes on Cigarettes, GATT Doc. DS 10/R-37S/200, adopted 7 November 1990, (Thailand Cigarettes).

United States - Restriction on Import of Tuna, Panel report Doc. DS 21/R, circulated at 3 September 1991 (unadopted), (US - Tuna/Dolphin I). 
United States - Restriction on Import of Tuna, Panel report Doc. DS 29/R, circulated at 16 June 1994 (unadopted), ('US - Tuna/Dolphin II').

United States - Tuna and Tuna Product from Canada, Panel Report (L/5198 - 29S/91), adopted 22 February 1982.

United States - Standard for Reformulated Gasoline and Conventional Gasoline, Panel Report (WT/DS2/AB/R), adopted 29 January 1996, (US - Reformulated Gasoline).

United States - Standard for the Reformulated and Conventional Gasoline, Report of the Appellate Body (WT/DS2/AB/R), adopted 29 April 1996.

United States - Import Prohibition of Shrimp and Shrimp Products, Appellate Body Report (WT/DS58/R/AB) adopted 12 October 1998, (US - Shrimp/Turtle I),

United States - Import Prohibition of Shrimp and Shrimp Products, Appellate Body Report (WT/DS58/R/AB/RW), 22 October 2001.

\section{Internet}

Chad P. Brown, "Developing Countries as Plaintiffs and Defendants in the GATT/WTO Trade Disputes", 1, <http://people.brandeis.edu/ cbown/ papers/developing.pdf $>$, accesed 5 January 2007

Directorate General of International Trade Cooperation of Republic of Indonesia, <http://www.ditjenkpi.go.id >.

Georgetown Law School, <http://www.law.georgetown.edu>, 13 January 2007.

Intergovernmental Panel on Climate Change, <http://www.ipcc.ch>, accesed 25 January 2006.

International Institute for Sustainable Development, $<\mathrm{http}$ ://www.iisd.org $>$.

Millennium Ecosystem Assessment, <http://www.millennium assessment.org>, accesed 18 January 2006.

World Trade Organization, <http://www.wto.org>, accesed 16 January 2006.

WorldTradeLaw.net, <http://www.worldtradelaw.net>, accesed 10 January 2006. 